Available online on 15.07 .2018 at jddtonline.info
Journal Of Drug Delivery and Therapeutics
$\begin{gathered}\text { Open Access to Pharmaceutical and Medical Research } \\ \text { (2011-18, publisher and licensee JDDT, This is an Open Access article which permits unrestricted non- } \\ \text { commercial use, provided the original work is properly cited }\end{gathered}$

Open $\odot$ Access

Review Article

\title{
MEDICINAL POTENTIAL OF LANTANA CAMARA: VERBENACEAE
}

\author{
Sunita Verma* \\ Assistant Professor, Department of Botany, Rakesh P.G. College, Pilani, Rajasthan, India
}

\section{ABSTRACT}

Lantana camara is a shrub that belongs to the family of Verbanaceae. Lantana camara is one such notorious weed which is affecting ecosystem, and causing biodiversity loss at greater extent. It is highly invasive and currently occupies a large percentage of the vegetation cover wherever it was introduced. But, Lantana camara is well known to cure several diseases and used in various folk medicinal preparations. It used in many pharmacological activities. These studies established the therapeutic potential of Lantana camara in modern medicines and a possible candidate for the drug discovery. The present review aims to document the taxonomy, ecology, morphology and medicinal properties of L. camara.

Keywords: Invasive, Ecology, Medicinal, Pharmacological, Weed.

Article Info: Received 17 April, 2018; Review Completed 20 June 2018; Accepted 22 June 2018; Available online 15 July 2018

Cite this article as:

Verma S, Medicinal potential of Lantana camara: verbenaceae, Journal of Drug Delivery and Therapeutics. 2018; 8(4):62-64 DOI: http://dx.doi.org/10.22270/jddt.v8i4.1771

*Address for Correspondence:

Sunita Verma, Assistant Professor, Department of Botany, Rakesh P.G. College, Pilani, Rajasthan, India

\section{INTRODUCTION}

In India, the Ayurvedic systems of medicine has been existing for over three thousand years, Charaka and Sushruta, two of the earliest Indian scholars had sufficient knowledge of the properties of the Indian medicinal plants. The Vedas are the epic poems, which contain rich material on the herbal medicine of that time 1. Medicinal plants have been used for years in daily life to treat disease all over the world ${ }^{2}$. A wide range of medicinal plant parts is used for extract as raw drugs and they possess varied medicinal properties ${ }^{3}$. People living in tribal localities and in villages are using indigenous plants as medicines from long ago because this knowledge reaches to them through generation to generation, and is based on experience 4 . The herbal drugs, which are cheap with less side effects, will be helpful to cure diseases of all the people including countries of the third world ${ }^{\mathbf{5}}$. In recent time, there has been a marked shift towards herbal cures because of the pronounced cumulative and irreversible reactions of modern drugs 6 .

India is abode of indigenous species and well known for its biodiversity hotspots. A large majority of exotics plaguing the country are natives of American continent, followed by Eurasia, Europe, Asia, Africa and Australia.
Although, a large number of exotics have reached naturalization in India; only a few have noticeably altered the ecosystem structure and functions. Amidst them, Lantana camara stands out distinctly in the list of top invaders $\mathbf{6 , 7 , 8}$.

Lantana camara is one such pantropical weed which is affecting ecosystem, and causing biodiversity loss at greater extent. It is a shrub that belongs to the family of Verbenaceae. Lantana camara is one of the notorious weeds causing dramatic and apparently irreversible degradation of natural communities in India. It is highly invasive and currently occupies a large percentage of the vegetation cover wherever it was introduced. Its growth poses a threat to other biodiversity. The species is native of Central and South America and the Caribbean with geographical expansion between $35^{\circ} \mathrm{N}$ and $35^{\circ} \mathrm{S}{ }^{10}$.

The present review aims to document the taxonomy, ecology, morphology and medicinal properties of $L$. camara.

\section{Taxonomy}

Kingdom : Planate

Division : Magnoliophyta

Class : Magnoliopsida 
Order : Lamiales

Family : Verbenaceae

Genus : Lantana

Species : Lantana camara

\section{Ecology}

Lantana camara's widespread and diverse distribution is a reflection of its wide ecological tolerances. The species occurs in varied habitats ranging from open unshaded regions which include wastelands, rainforest edges, beachfronts, and forests disturbed by activities such as fire or logging 11. The species also thrive well in disturbed areas which include roadside, railway tracks and canals 12, 13, 14. Anthropogenic activity further aggravates the invasion and allows it to spread ${ }^{\mathbf{1 0}}$.

\section{Botanical Characters}

L. camara is a low erect or subscandent vigorous shrub with tetrangular stem, stout recurved pickles and a strong odour of black currents. Plant grows up to 1 to 3 meters and it can spread to 2.5 meter in width. Leaves are ovate or ovate oblong, acute or sub acute, crenate serrate, rugose above, scabrid on both sides. The leaves are $3-8 \mathrm{~cm}$ long by $3-6 \mathrm{~cm}$ wide and green in colour. Leaves and stem are covered with rough hairs. Small flower held in clusters (called umbels). Colour usually orange, sometime varying from white to red in various shades and the flower usually change colours as they ages. Flowers are having a yellow throat, in axillary head almost throughout the year. The calyx is small, corolla tube slender, the limb spreading 6 to $7 \mathrm{~mm}$ wide and divided in to unequal lobes. Stamen four in two pairs, included and ovary two celled, two ovule. Inflorescences are produced in pairs in the axils of opposite leaves. Inflorescences are compact, dome shaped 2-3 cm across and contain 20-40 sessile flowers. Root system is very strong and it gives out new fresh shoots even after repeated cuttings ${ }^{15}$.
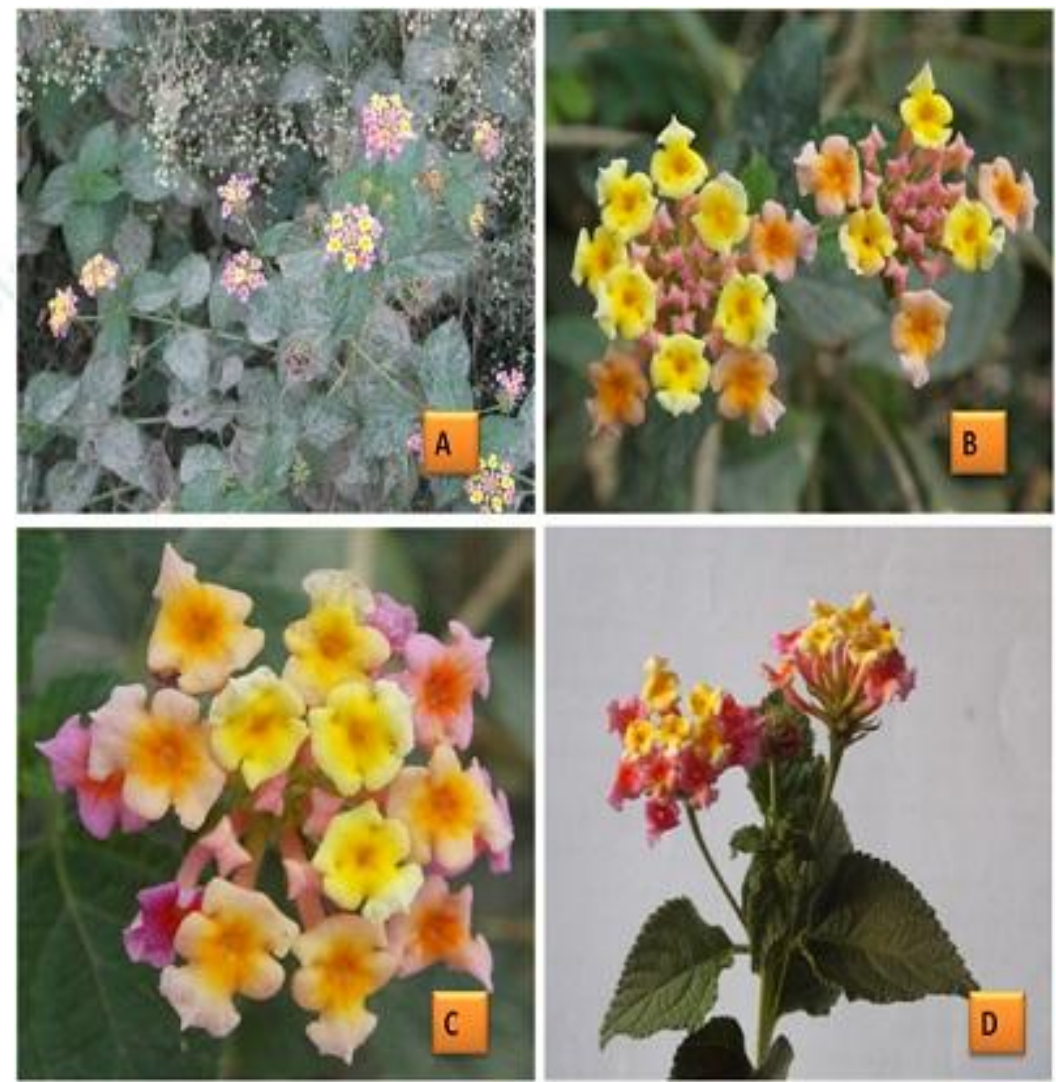

Figure 1: Whole plant of Lantana Camara

\section{Medicinal Uses}

Medicinal plants are an important source of drugs in traditional system of medicine ${ }^{\mathbf{1 6}}$. Lantana camara has several therapeutic uses, mainly as herbal medicine ${ }^{17,18,}$ 19. There has been much work conducted in India on the chemical constituents of Lantana camara; extracts from the leaves exhibit antimicrobial, fungicidal, insecticidal, nematicidal, biocidal activity ${ }^{20}$. Plant extracts are used as medicine for the treatment of cancers, chicken pox, measles, asthma, ulcers, swellings, eczema, tumors, high blood pressure, bilious fevers, catarrhal infections, tetanus, rheumatism, malaria and atoxy of abdominal viscera ${ }^{21}$. It is further reported that verbacoside, a compound isolated from lantana extract has been demonstrated to possess anti microbial immunosuppressive and anti tumour activities. Use of lantana oil in treatment of skin itches and as an antiseptic for wounds and externally for leprosy and scabies is also reported ${ }^{\mathbf{2 2}}$. 


\section{CONCLUSION}

Lantana camara (Verbenaceae) is one of the wellknown medicinal plants in traditional medicine. It is also popular in folkloric treatment as cure to various ailments including rheumatism, wound, fever, and asthma in various tribal community. L. camara is also known as an

\section{REFERRENCES}

1. Alice K. and Asha S. 2007. Medicinal Plants Horticulture Sciences, New India, New India publication agency. 2: 1.

2. Verma, S. (2016). A Review on Ziziphus numularia: Valuable Medicinal Plant of Desert. World Journal of Pharmacy and Pharmaceutical Sciences. 5(3): 539-542.

3. Verma S. A Review on Ethnomedicinal Plant Acacia nilotica (Linn.) wild. Journal of Pharmacognosy and Phytochemistry. 2016; 5(2):241-242.

4. Pathak S, Mishra J.K. Some ethnomedicinal plants of Sheopur district, MP. Ind J Sci Res., 2011; 2:133-134.

5. Verma S. Medicinal Plants Used in Cure of Skin Diseases. Advances in Applied Science Research. 2016; 7(3):65-67.

6. Verma S. A Review Study on Achyranthes aspera (Amaranthaceae)- A valuable Medicinal Herb. Journal of Medicinal Plant Studies. 2016; 4(3):06-07.

7. Hiremath J. and Sundaram B. The fire-Lantana cycle hypothesis in Indian forests. Conservation and Society. 2005; 3:26-42.

8. Sharma G.P. and Raghubanshi, A.S. How Lantana invades dry deciduous forest: a case study from Vindhyan highlands, India. Tropical Ecology. 2010; 51(2S): 305-316.

9. Prasad A.M., Iverson L.R. and Liaw A. Newer classification and regression techniques: bagging and random forests for ecological prediction. Ecosystems. 2006; 9:181-199.

10. Sahu P.K. and Singh J.S. Structural attributes of lantanainvaded forest plots in Achanakmar-Amarkantak Biosphere Reserve, Central India. Current Science. 2008; 94(4):494-500.

11. Day M.D., Wiley C.J., Playford J. and Zalucki M.P. Lantana: Current Management, Status and Future Prospects. Australian Centre for International Agricultural Research. 2003; 5:1- 20.

12. Thakur M.L., Ahmad M. and Thakur R.K. Lantana weed (Lantana camara var. aculeata Linn) and its possible management through natural insect pests in India. Indian Forester. 1992; 118:466-488.

13. Sharma G.P., Raghubanshi A.S. and Singh J.S. Lantana invasion: An overview. Weed Biology Management. 2005; 5:157-167. ornamental weed in various regions. Its flexible nature makes the plant invasive, widely distributed and turns a problematic weed due to its dominant nature. So, new strategies should be developed to optimize the usefulness of this plant such as exploring its pharmacologic potential.

14. Kohli R.K., Batish D.R., Singh H.P. and Dogra K.S. Status, invasiveness and environmental threats of three tropical American invasive weeds (Parthenium hysterophorus L., Ageratum conyzoides L., Lantana camara L.) in India. Biological Invasion. 2006; 8:1501-1510.

15. Dogra K.S., Kohli R.K. and Sood S.K. An assessment and impact of three invasive species in the Shivalik hills of Himachal Pradesh, India. International Journal of Biodiversity and Conservation. 2009; 1(1):4-10.

16. Sastri B.N. 1962. The wealth of India. CSIR New Delhi, India.

17. Verma S. Calotropis procera (Asclepiadaceae): A Review. International Journal of Scientific Research in Science and Technology. 2016; 2(6):487-490.

18. Sharma O.P., Makkar H.P.S. and Dawra R.K. A review of the noxious plant Lantana camara. Toxicon. 1988; 26:975-987.

19. Sharma O.P and Sharma P.D. Natural products of the Lantana plant -the present and prospects. Journal of Scientific \& Industrial Research. 1989; 48:471-478.

20. Sharma S., Singh A. and Sharma O. P. An improved procedure for isolation and purification of lantadene $\mathrm{A}$, the bioactive pentacyclic triterpenoid from Lantana camara leaves. Journal of Medicinal and Aromatic Plant Science. 1999; 21:686-688.

21. Sharma O. P., Sharma S., Pattabhi V., Mahato S. B. and Sharma P. D. A Review of the Hepatotoxic Plant. Lantana camara. Journal of Scientific \& Industrial Research. 2007; 37:313-352.

22. Begum S., Wahab A. and Siddiqui B. S. Pentacyclic triterpenoids from the aerial parts of Lantana camara. Chemical and Pharmaceutical Bulletin. 2000; 51:134-137.

23. Jimenez-Arellanes A., Meckes M., Ramirez R., Torres J. and LunaHerrera J. Activity against multidrug-resistant Mycobacterium tuberculosis in Mexican plants used to treat respiratory diseases. Phytother Res. 2003; 17(8):903-8. 